REVIEW ARTICLE

\title{
Current and alternative trends in antibacterial agents used in mammalian semen technology
}

\author{
Caio Sérgio Santos ${ }^{1}$ (D) Alexandre Rodrigues Silva ${ }^{1 \star}$ (D) \\ 1Departamento de Ciências Animais, Universidade Federal Rural do Semi-Árido, Mossoró, RN, Brasil
}

How to cite: Santos CS, Silva AR. Current and alternative trends in antibacterial agents used in mammalian semen technology. Anim Reprod. 2020;17(1):e20190111. https://doi.org/10.21451/1984-3143-AR2019-0111

\begin{abstract}
The use of antibacterial substances as additives in extenders for ensuring the sanitary quality of the semen employed in reproductive biotechniques and preserving it from bacterial deterioration has been reported since the mid-twentieth century. However, the deleterious effects of these drugs on the sperm quality as well as their effectiveness in controlling bacterial growth in the preserved semen have been questioned. The aim of this review was to report the antimicrobials primarily used in the extenders added to the semen of mammals, and to present alternatives to their use. Among the various mammalian species, there is a large variation regarding the antimicrobial types added to semen extenders as cephalosporins (ceftiofur, cefdinir, eg) and quinolones (ofloxacin, ciprofloxacin), alone or in combination with large action spectra substances as penicillin-streptomycin and gentamicin-tylosin-lincomycin-spectinomycin. To combat problems related to bacterial resistance to these drugs, the emergence of alternatives is increasingly evident. Among these alternatives, use of physical methods as centrifugation and filtration, as well as the use of antimicrobial peptides and other substances from different origins have been highlighted for presenting antimicrobial potential.
\end{abstract}

Keywords: antibiotic, bacteria, chilling, cryopreservation, extenders.

\section{Introduction}

Reproduction plays an important role in ensuring the efficiency of animal production (Woelders et al., 2012), maintaining their biodiversity, and supporting the conservation programs of vulnerable or threatened species (Costa and Martins, 2008). Thus, assisted reproductive techniques such as artificial insemination (Al) associated with semen technology allow the preserved male genetic material to be used in females that are isolated from the males. This maximizes the availability of the germplasm and facilitates genetic improvement, disease control and conducting of reproductive procedures regardless of time and geographical location (Morrell and Mayer, 2017).

Although one of the benefits of $\mathrm{Al}$ is to reduce the spread of diseases, this technique may allow the pathogens to be easily disseminated through the transmission of contaminated semen (Foote, 2002). The semen can be contaminated particularly during the process of its collection or cryopreservation if good practices are not adopted (Zampieri et al., 2013). Moreover, the presence of pathogens can damage the sperms (Diemer et al., 2000), adversely affecting the quality of the semen subjected to cryopreservation.

For these reasons, in order to prevent bacterial multiplication, antibacterial substances are usually added to the diluents during the cryopreservation procedures. Contrarily, some of these substances can affect the survival of sperm, the use of which can sometimes be restricted due to active regulations. Moreover, their indiscriminate use can lead to bacterial resistance,

*Correspondence: Alexandre Rodrigues Silva, alexrs@ufersa.edu.br

Received: September 24, 2019. Accepted: February 10, 2020.

Financial support: ARS receives a grant from the National Council for the Scientific Development (CNPq, Process N. 303929/2018-9).

Conflict of interest: The authors have no conflict of interest to declare.

(c) (i) Copyright (c) The Author(s). This is an Open Access article distributed under the terms of the Creative Commons Attribution License, which permits unrestricted use, distribution, and reproduction in any medium, provided the original work is properly cited. 
even when utilized in small quantities (Morrell and Wallgren, 2011). At this sense, this review aims to report the main antimicrobial agents added to mammalian semen extenders and the factors related to their effectiveness, as well as presenting alternatives to their use.

\section{Sources and consequences of bacterial contamination in semen technology}

Some microorganisms are present in the semen because they cross the bloodstream of the animals suffering from bacteremia. Others may come from the preputial microbiota of healthy semen donors and associate themselves with the semen during ejaculation and collection. Contamination can also occur during the processing and storage of semen, which may be derived not only from the environment but also from substances (particularly of animal origin, such as egg yolk) added to the semen extenders, equipment and materials such as storage bottles, which are in direct or indirect contact with the semen (Thibier and Guerin, 2000). Liquid nitrogen is an effective cryopreservant of pathogens and may also be an unsuspected source of contamination. This emphasizes on the need for care during the storage of semen, which should be carried out using well-protected and sealed straws (Mazurova and Krpatova, 1990).

Microorganisms can cause serious economic damages by reducing the semen quality and possible dissemination of pathogens (Prieto-Martínez et al., 2014). Contaminated semen can reduce the conception rate, cause early embryonic death and/or endometritis, clinical diseases in herds, and/or infections by unwanted pathogens (Maes et al., 2008).

It has been reported that microbes affect and interfere with the semen quality. It was verified that the presence of bacteria can cause morphological alterations, acrosome exocytosis (Prieto-Martínez et al., 2014), sperm agglutination, decreased sperm motility and membrane integrity (Sepúlveda et al., 2014), decrease in the sperm longevity within $48 \mathrm{~h}$ of collection and processing (regardless of whether the diluent used is for short, medium or long term), and also causes acidification of the medium (pH between 5.7 and 6.4) (Althouse et al., 2000).

In general, it is known that the semen collection process is far from being a sterile procedure because of the involvement of multiple sources that can lead to bacterial contamination (Bussalleu and Torner, 2013). In this sense, additional measures such as regular monitoring of the animals and semen, biosafety measures to reduce contamination during collection, processing and storage, and the treatment of semen with the appropriate antimicrobials (Maes et al., 2008) are necessary.

\section{International regulations}

Several countries require the assessment of animal health for the importation of semen obtained from production animals like cattle, buffaloes, goats, sheep, horses and pigs. The regulations recommend the use of antimicrobials in semen extenders as a measure to prevent the spread of diseases and sperm degradation.

With the development of the semen trade using farm animals, regulations set by the European Union and the European Council (EEC), which required the use of antibacterial cocktails at inseminating doses, emerged in the late 1980s and early 1990s. According to the Directives 88/407 and 90/429 of the European Council, Annex C2, which lays down the health policy requirements for intra-community trade and imports of bovine and porcine semen, respectively, it is stated that an effective combination of antimicrobials, particularly against leptospires and mycoplasmas, should be added to the semen after the final dilution (European Union, 1988, 1990). The EEC directive 92/65 (European Union, 1992), which applies to other animals such as Equidae, swine and small ruminants, reports another combination of antimicrobials consisting of gentamicin $(250 \mu \mathrm{g} / \mathrm{mL})$, tylosin $(50 \mu \mathrm{g} / \mathrm{mL})$ and lincomycin/spectinomycin $(150 / 300 \mu \mathrm{g} / \mathrm{mL})$, or amikacin $(75 \mu \mathrm{g} / \mathrm{mL})$ and divecacin $(25 \mu \mathrm{g} / \mathrm{mL})$, which can be used alone (EEC directive 92/65).

Some Latin American countries also have a legislation establishing the minimum sanitary requirements for the processing and marketing of animal semen. For instance, in Brazil, laws 
were established only more than a decade after the implementation of the European regulations. Normative instructions for cattle (Brasil, 2003), goats and sheep (Brasil, 2014) recommended the same combination of substances used by the European Directives. However, regulations concerning the importation of swine and equine semen from the Mercosur countries neither define the substances nor the doses that may be added to the diluents.

\section{Use of antibacterial substances in semen extenders}

The antimicrobials frequently used in mammalian semen diluents include the $\beta$-lactams (penicillins, cephalosporins), which interfere with the process of bacterial cell wall synthesis, causing lysis and cell death (Spinosa et al., 2011). Others include the aminoglycosides (gentamicin, streptomycin, amikacin), macrolides (tylosin, spectinomycin) and lincosamides (lincomycin), which are inhibitors of bacterial protein synthesis (Spinosa et al., 2011). Among the various mammalian species, however, there is a large variation regarding the antimicrobial types and concentrations added to extenders used for both chilling or freezing semen procedures.

Studies on bacterial control in ruminants (Table 1) date from the 40s and 50 s in the United States of America, emphasizing the importance of its use in the development of artificial insemination (Al) in bovine. Initially, the antimicrobials most used in bovine semen technology were penicillin and streptomycin (Almquist et al., 1949). Almquist (1951) reported their use at concentrations of $1000 \mathrm{IU} / \mathrm{mL}$ and $1000 \mu \mathrm{g} / \mathrm{mL}$, respectively, in an egg yolk citrate diluent and their combined use demonstrated better herd fertility results than when used alone. Two years later, Alford (1953) evidenced that diphtheroid bacilli demonstrated resistance even when high concentrations of streptomycin were added to the bovine semen. Nowadays, the use of a combination of gentamicin-tylosin-lincomycin-spectinomycin $(500 \mu \mathrm{g} / \mathrm{mL}-100 \mu \mathrm{g} / \mathrm{mL}-300$ $\mu \mathrm{g} / \mathrm{mL}-600 \mu \mathrm{g} / \mathrm{mL}$, respectively) is largely recommended for diluting the semen of several species, including bulls and buffaloes (Andrabi et al., 2001; Akhter et al., 2008; Andrabi et al., 2016). In spite of this, other antimicrobial combinations, as the ceftiofur/tylosin $(200 \mu \mathrm{g} / \mathrm{mL}-100 \mu \mathrm{g} / \mathrm{mL})$ and ofloxacin $(100 \mu \mathrm{g} / \mathrm{mL})$ have been highlighted for a more effective control of the bacterial growth in bovine semen (Gloria et al., 2014). Besides, the use of ciprofloxacin $(600 \mu \mathrm{g} / \mathrm{ml})$ added to the Tris-citric acid diluent has been also recommended for the preservation of buffaloes' semen (Akhter et al., 2013). On the other hand, the use of cephalosporin as cefdinir $(1 \mathrm{mg} / \mathrm{mL})$ and cefoperazone sodium $(1 \mathrm{mg} / \mathrm{mL})$ was effective for controlling bacteria during ram semen chilling at $5{ }^{\circ} \mathrm{C}$ up to $96 \mathrm{~h}$ (Azawi and Ismaeel, 2012). In the same species, the use of streptomycin-penicillin combination was more effective to bacterial control than lincomycin and sulfadiazine, without causing negative effects on sperm (Moustacas et al., 2010).

Table 1. Some antimicrobial substances successfully used in mammalian semen technology.

\begin{tabular}{|c|c|c|c|c|c|c|}
\hline & Antimicrobials & $\begin{array}{c}\text { Concentration } \\
\text { s }\end{array}$ & $\begin{array}{l}\text { Semen } \\
\text { diluents }\end{array}$ & $\begin{array}{c}\text { Storage } \\
\text { temperatures }\end{array}$ & $\begin{array}{l}\text { Storage } \\
\text { times }\end{array}$ & References \\
\hline \multirow{4}{*}{ Bulls } & $\begin{array}{l}\text { Streptomycin and } \\
\text { penicillin }\end{array}$ & $\begin{array}{c}100 \text { to } 1000 \\
\mu g / m L \text { or } \\
\mathrm{IU} / \mathrm{mL} \text { of each }\end{array}$ & $\begin{array}{c}\text { Sodium } \\
\text { citrate-egg } \\
\text { yolk }\end{array}$ & $4,5^{\circ} \mathrm{C}$ & 20 days & $\begin{array}{c}\text { Almquist et al. } \\
\text { (1949) }\end{array}$ \\
\hline & $\begin{array}{c}\text { Streptomycin and } \\
\text { penicillin (alone } \\
\text { or combination) }\end{array}$ & $\begin{array}{c}1,000 \mathrm{mg} / \mathrm{mL} \\
\text { and } 1,000 \\
\mathrm{IU} / \mathrm{mL}\end{array}$ & $\begin{array}{c}\text { Sodium } \\
\text { citrate-egg } \\
\text { yolk }\end{array}$ & - & - & Almquist (1951) \\
\hline & $\begin{array}{c}\text { Gentamicin, } \\
\text { tylosin, } \\
\text { lincomycin and } \\
\text { spectinomycin }\end{array}$ & $\begin{array}{c}500 \mu \mathrm{g} / \mathrm{mL}, \\
100 \mu \mathrm{g} / \mathrm{mL}, \\
300 \mu \mathrm{g} / \mathrm{mL} \\
\text { and } 600 \\
\mu \mathrm{g} / \mathrm{mL}\end{array}$ & $\begin{array}{l}\text { Tris-citric } \\
\text { acid }\end{array}$ & $-196^{\circ} \mathrm{C}$ & 1 day & $\begin{array}{c}\text { Andrabi et al. } \\
\text { (2001) }\end{array}$ \\
\hline & $\begin{array}{l}\text { Ceftiofur and } \\
\text { tylosin }\end{array}$ & $\begin{array}{c}200 \mu g / m L \\
\text { and } 100 \\
\mu g / m L\end{array}$ & $\begin{array}{c}\text { Bioxcell } \\
\text { CSS I and II }\end{array}$ & $-145^{\circ} \mathrm{C}$ & 7 days & Gloria et al. (2014) \\
\hline
\end{tabular}


Table 1. Continued...

\begin{tabular}{|c|c|c|c|c|c|c|}
\hline & Antimicrobials & $\begin{array}{c}\text { Concentration } \\
\mathrm{S}\end{array}$ & $\begin{array}{l}\text { Semen } \\
\text { diluents }\end{array}$ & $\begin{array}{c}\text { Storage } \\
\text { temperatures }\end{array}$ & $\begin{array}{l}\text { Storage } \\
\text { times }\end{array}$ & References \\
\hline & Ofloxacin & $100 \mu g / m L$ & $\begin{array}{c}\text { Bioxcell } \\
\text { CSS I and II }\end{array}$ & $-145^{\circ} \mathrm{C}$ & 7 days & Gloria et al. (2014) \\
\hline \multirow[t]{4}{*}{ Buffaloes } & $\begin{array}{l}\text { Gentamicin, } \\
\text { tylosin, } \\
\text { lincomycin and } \\
\text { spectinomycin }\end{array}$ & $\begin{array}{c}500 \mu \mathrm{g} / \mathrm{mL}, \\
100 \mu \mathrm{g} / \mathrm{mL}, \\
300 \mu \mathrm{g} / \mathrm{mL} \\
\text { and } 600 \\
\mu \mathrm{g} / \mathrm{mL}\end{array}$ & $\begin{array}{l}\text { Skimmed } \\
\text { milk based }\end{array}$ & $5^{\circ} \mathrm{C}$ & 3 days & $\begin{array}{l}\text { Akhter et al. } \\
\text { (2008) }\end{array}$ \\
\hline & $\begin{array}{l}\text { Streptomycin and } \\
\text { penicillin } \mathrm{G}\end{array}$ & $\begin{array}{c}1,000 \mathrm{mg} / \mathrm{mL} \\
\text { and } 1,000 \\
\mathrm{IU} / \mathrm{mL}\end{array}$ & $\begin{array}{l}\text { Skimmed } \\
\text { milk based }\end{array}$ & $5^{\circ} \mathrm{C}$ & 3 days & $\begin{array}{l}\text { Akhter et al. } \\
\text { (2008) }\end{array}$ \\
\hline & Ciprofloxacin & $600 \mu \mathrm{g} / \mathrm{mL}$ & $\begin{array}{l}\text { Tris-citric } \\
\text { acid }\end{array}$ & $-196^{\circ} \mathrm{C}$ & - & $\begin{array}{l}\text { Akhter et al. } \\
\text { (2013) }\end{array}$ \\
\hline & $\begin{array}{l}\text { Gentamicin, } \\
\text { tylosin, } \\
\text { lincomycin and } \\
\text { spectinomycin }\end{array}$ & $\begin{array}{c}500 \mu \mathrm{g} / \mathrm{mL}, \\
100 \mu \mathrm{g} / \mathrm{mL}, \\
300 \mu \mathrm{g} / \mathrm{mL} \\
\text { and } 600 \\
\mu \mathrm{g} / \mathrm{mL}\end{array}$ & $\begin{array}{l}\text { Tris-citric } \\
\text { acid }\end{array}$ & $-196^{\circ} \mathrm{C}$ & 1 day & $\begin{array}{l}\text { Andrabi et al. } \\
\qquad(2016)\end{array}$ \\
\hline \multirow{4}{*}{ Rams } & $\begin{array}{l}\text { Streptomycin and } \\
\text { penicillin } \mathrm{G}\end{array}$ & $\begin{array}{c}1,000 \mathrm{mg} / \mathrm{mL} \\
\text { and } 1,000 \\
\mathrm{IU} / \mathrm{mL}\end{array}$ & $\begin{array}{l}\text { Tris- } \\
\text { glucose }\end{array}$ & $-196^{\circ} \mathrm{C}$ & - & $\begin{array}{c}\text { Moustacas et al. } \\
(2010)\end{array}$ \\
\hline & Gentamicin & $250 \mu \mathrm{g} / \mathrm{mL}$ & $\begin{array}{l}\text { Tris- } \\
\text { glucose }\end{array}$ & $-196^{\circ} \mathrm{C}$ & - & $\begin{array}{c}\text { Moustacas et al. } \\
(2010)\end{array}$ \\
\hline & Cefdinir & $1.0 \mathrm{mg} / \mathrm{mL}$ & $\begin{array}{l}\text { Sodium } \\
\text { citrate- } \\
\text { fructose- } \\
\text { egg yolk }\end{array}$ & $5^{\circ} \mathrm{C}$ & 4 days & $\begin{array}{l}\text { Azawi and Ismaeel } \\
\text { (2012) }\end{array}$ \\
\hline & $\begin{array}{l}\text { Cefoperazone } \\
\text { sodium }\end{array}$ & $1.0 \mathrm{mg} / \mathrm{mL}$ & $\begin{array}{l}\text { Sodium } \\
\text { citrate- } \\
\text { fructose- } \\
\text { egg yolk }\end{array}$ & $5^{\circ} \mathrm{C}$ & 4 days & $\begin{array}{l}\text { Azawi and Ismaeel } \\
\text { (2012) }\end{array}$ \\
\hline \multirow{5}{*}{ Boars } & Gentamicin & - & - & $18^{\circ} \mathrm{C}$ & 3 days & $\begin{array}{l}\text { Mazurová and } \\
\text { Vinter (1991) }\end{array}$ \\
\hline & $\begin{array}{l}\text { Gentamicin and } \\
\text { florfenicol }\end{array}$ & $\begin{array}{c}100 \mu g / m L \\
\text { and } 100 \\
\mu g / m L\end{array}$ & $\begin{array}{l}\text { Biosolwen } \\
\text { s Plus }\end{array}$ & $15^{\circ} \mathrm{C}$ & 10 days & $\begin{array}{c}\text { Bryła and } \\
\text { Trzcinska (2015) }\end{array}$ \\
\hline & Gentamicin & $250 \mu \mathrm{g} / \mathrm{mL}$ & $\begin{array}{l}\text { Beltsvile } \\
\text { Thowing } \\
\text { Solution }\end{array}$ & $17^{\circ} \mathrm{C}$ & 3 days & $\begin{array}{l}\text { Waberski et al. } \\
\text { (2019) }\end{array}$ \\
\hline & Gentamicin & $250 \mu \mathrm{g} / \mathrm{mL}$ & $\begin{array}{l}\text { Androstar } \\
\text { Premium }\end{array}$ & $17^{\circ} \mathrm{C}$ & 3 days & $\begin{array}{l}\text { Waberski et al. } \\
\text { (2019) }\end{array}$ \\
\hline & - & - & $\begin{array}{l}\text { Androstar } \\
\text { Premium * }\end{array}$ & $5^{\circ} \mathrm{C}$ & 3 days & $\begin{array}{c}\text { Waberski et al. } \\
\text { (2019) }\end{array}$ \\
\hline \multirow{5}{*}{ Stallions } & Amikacin & $2,500 \mu \mathrm{g} / \mathrm{mL}$ & $\begin{array}{l}\text { Tris-egg } \\
\text { yolk }\end{array}$ & $4{ }^{\circ} \mathrm{C}$ & 7 days & $\begin{array}{c}\text { Arriola and Foote } \\
\text { (1982) }\end{array}$ \\
\hline & $\begin{array}{l}\text { Amikacin or } \\
\text { Ticarcillin }\end{array}$ & $2,000 \mu \mathrm{g} / \mathrm{mL}$ & $\begin{array}{l}\text { Skim milk- } \\
\text { glucose }\end{array}$ & $\begin{array}{c}23^{\circ} \mathrm{C} \text { and } 5^{\circ} \mathrm{C} \text {, } \\
\text { respectively }\end{array}$ & $\begin{array}{c}\text { 1h and } 2 \\
\text { days, } \\
\text { respectivel } \\
\text { y }\end{array}$ & Jasko et al. (1993) \\
\hline & $\begin{array}{l}\text { Gentamicin or } \\
\text { polimixin B }\end{array}$ & $\begin{array}{l}100 \mu \mathrm{g} / \mathrm{mL} \text { or } \\
1,000 \mathrm{IU} / \mathrm{mL} \\
\text { respectively }\end{array}$ & $\begin{array}{l}\text { Skim-milk } \\
\text { glucose }\end{array}$ & $\begin{array}{l}20^{\circ} \mathrm{C} \text { and } 5^{\circ} \mathrm{C}, \\
\text { respectively }\end{array}$ & $\begin{array}{l}\text { 8h and } 2 \\
\text { days, } \\
\text { respectivel } \\
\text { y }\end{array}$ & $\begin{array}{c}\text { Vaillancourt et al. } \\
\qquad(1993)\end{array}$ \\
\hline & $\begin{array}{l}\text { Penicillin G and } \\
\text { amikacin or } \\
\text { Ticarcillin- } \\
\text { clavulanic acid or } \\
\text { Ceftiofur }\end{array}$ & $\begin{array}{c}1,000 \mathrm{IU} / \mathrm{mL} \\
\text { and } 1,000 \\
\mu \mathrm{g} / \mathrm{mL} \text { or } \\
1,000 \mu \mathrm{g} / \mathrm{mL} \\
\text { or } 1,000 \\
\mu \mathrm{g} / \mathrm{mL}\end{array}$ & $\begin{array}{l}\text { Skim-milk } \\
\text { glucose }\end{array}$ & $5^{\circ} \mathrm{C}$ & 1 day & $\begin{array}{c}\text { Varner et al. } \\
\text { (1998) }\end{array}$ \\
\hline & Gentamicin & $250 \mu \mathrm{g} / \mathrm{mL}$ & EquiPro $^{\odot}$ & $15^{\circ} \mathrm{C}$ & 4 days & Price et al. (2008) \\
\hline
\end{tabular}


Table 1. Continued...

\begin{tabular}{|c|c|c|c|c|c|c|}
\hline & Antimicrobials & $\begin{array}{c}\text { Concentration } \\
\mathrm{S}\end{array}$ & $\begin{array}{l}\text { Semen } \\
\text { diluents }\end{array}$ & $\begin{array}{c}\text { Storage } \\
\text { temperatures }\end{array}$ & $\begin{array}{l}\text { Storage } \\
\text { times }\end{array}$ & References \\
\hline & - & - & EquiPro ${ }^{\odot}$ * & $5^{\circ} \mathrm{C}$ & 4 days & Price et al. (2008) \\
\hline & Cefquinome & $0.99 \mathrm{mg} / \mathrm{mL}$ & EquiPro $^{\odot}$ & $5^{\circ} \mathrm{C}$ & 2 days & $\begin{array}{c}\text { Parlevliet et al. } \\
\qquad(2011)\end{array}$ \\
\hline & $\begin{array}{c}\text { Ticarcillin- } \\
\text { clavulanic acid }\end{array}$ & $\begin{array}{c}0.5,1.0 \text { and } \\
1.5 \mathrm{mg} / \mathrm{mL}\end{array}$ & INRA $96^{\circledR ~} * \star$ & $5^{\circ} \mathrm{C}$ & 3 days & $\begin{array}{l}\text { Olivieri et al. } \\
\text { (2011) }\end{array}$ \\
\hline & $\begin{array}{c}\text { Penicillin } \mathrm{G} \text { and } \\
\text { amikacin }\end{array}$ & $\begin{array}{c}\text { As supplied by } \\
\text { the } \\
\text { manufacturer }\end{array}$ & VDMZ & $5^{\circ} \mathrm{C}$ & 3 days & $\begin{array}{c}\text { Olivieri et al. } \\
\qquad(2011)\end{array}$ \\
\hline & $\begin{array}{l}\text { Penicillin G and } \\
\text { gentamicin }\end{array}$ & $\begin{array}{c}1,000 \mathrm{IU} / \mathrm{mL} \\
\text { and } 1,000 \\
\mathrm{mg} / \mathrm{mL}\end{array}$ & BotuSemen $^{\circledR}$ & 5 and $15^{\circ} \mathrm{C}$ & 1 day & $\begin{array}{c}\text { Ramires } \\
\text { Neto et al. (2015) }\end{array}$ \\
\hline & $\begin{array}{c}\text { Penicillin } G \text { and } \\
\text { amikacin }\end{array}$ & $\begin{array}{c}1,000 \mathrm{IU} / \mathrm{mL} \\
\text { and } 1,000 \\
\mathrm{mg} / \mathrm{mL}\end{array}$ & TAMU & Fresh and $5^{\circ} \mathrm{C}$ & 1 day & $\begin{array}{c}\text { Hernández- } \\
\text { Avilés et al. (2018) }\end{array}$ \\
\hline & Meropenem & $1,000 \mathrm{mg} / \mathrm{mL}$ & TAMU & Fresh and $5^{\circ} \mathrm{C}$ & 1 day & $\begin{array}{c}\text { Hernández- } \\
\text { Avilés et al. (2018) }\end{array}$ \\
\hline & $\begin{array}{l}\text { Penicillin } \mathrm{G} \text { and } \\
\text { amikacin }\end{array}$ & $\begin{array}{c}1,000 \mathrm{IU} / \mathrm{mL} \\
\text { and } 1,000 \\
\mathrm{mg} / \mathrm{mL}\end{array}$ & INRA $96^{\circledR} \star \star *$ & Fresh and $5^{\circ} \mathrm{C}$ & 1 day & $\begin{array}{c}\text { Hernández- } \\
\text { Avilés et al. (2019) }\end{array}$ \\
\hline Dogs & $\begin{array}{l}\text { Gentamicin, } \\
\text { tylosin, } \\
\text { lincomycin and } \\
\text { spectinomycin }\end{array}$ & $\begin{array}{c}250,50,150 \\
\text { and } 300 \\
\mu \mathrm{g} / \mathrm{ml} ; \\
500,100,300 \\
\text { and } 600 \\
\mu \mathrm{g} / \mathrm{ml} ; \text { and } \\
1000,200,600 \\
\text { and } 1200 \\
\mu \mathrm{g} / \mathrm{ml}\end{array}$ & $\begin{array}{l}\text { Tris-citric } \\
\text { acid- } \\
\text { fructose- } \\
\text { egg yolk }\end{array}$ & $5^{\circ} \mathrm{C}$ & 3 days & $\begin{array}{l}\text { Becher et al. } \\
\text { (2013) }\end{array}$ \\
\hline $\begin{array}{c}\text { Koala } \\
\text { (Phascolarct } \\
\text { os cinereus) }\end{array}$ & $\begin{array}{l}\text { Penicillin G and } \\
\text { gentamicin }\end{array}$ & $\begin{array}{c}1,000 \mathrm{IU} / \mathrm{mL} \\
\text { and } 100 \\
\mu \mathrm{g} / \mathrm{mL}\end{array}$ & PBS & $16^{\circ} \mathrm{C}$ & 1 day & $\begin{array}{c}\text { Johnston et al. } \\
\qquad(1998)\end{array}$ \\
\hline \multirow{2}{*}{$\begin{array}{l}\text { Collared } \\
\text { peccaries } \\
\text { (Pecari } \\
\text { tajacu) }\end{array}$} & $\begin{array}{l}\text { Streptomycin and } \\
\text { penicillin G }\end{array}$ & $\begin{array}{c}1,000 \mathrm{mg} / \mathrm{mL} \\
\text { and } 1,000 \\
\mathrm{IU} / \mathrm{mL}\end{array}$ & $\begin{array}{l}\text { Tris-citric } \\
\text { acid- } \\
\text { fructose- } \\
\text { egg yolk }\end{array}$ & $5^{\circ} \mathrm{C}$ & 1,5 days & $\begin{array}{l}\text { Santos et al. } \\
\text { (2019b) }\end{array}$ \\
\hline & Gentamicin & $70 \mu \mathrm{g} / \mathrm{mL}$ & $\begin{array}{l}\text { Tris-citric } \\
\text { acid- } \\
\text { fructose- } \\
\text { egg yolk }\end{array}$ & $5^{\circ} \mathrm{C}$ & 1,5 days & $\begin{array}{l}\text { Santos et al. } \\
\text { (2019a) }\end{array}$ \\
\hline
\end{tabular}

*Antibiotic-free diluents; **It contains penicillin (105 $\mu \mathrm{g})$, streptomycin (38 $\mu \mathrm{g})$ and amphotericin B (0.315 $\mu \mathrm{g})$ on its composition.

As early as 1968, studies had indicated that the bacteria isolated from porcine semen were also resistant to some antibacterials such as penicillin-streptomycin (Almond and Poolperm, 1996). At this sense, in the 1990s, Mazurová and Vinter (1991) reported a decrease in bacterial contamination $\left(<10^{3}\right)$ of boar semen after dilution in a gentamicin-treated diluent incubated at $18^{\circ} \mathrm{C}$ for up to $72 \mathrm{~h}$. This study was pioneering at comparing gentamicin with several other antimicrobials such as ampicillin, apramycin and cefoxitin. Currently, gentamicin has established itself as one of the most used antimicrobials in boar semen diluents (Schulze et al., 2017). However, Gączarzewicz et al. (2016) demonstrated that the inhibitory activity of even gentamicin may be limited during long-term preservation $\left(16^{\circ} \mathrm{C}\right.$ for five days) in diluent (X-cell $\left.{ }^{\circledR}\right)$. In fact, the storage time is an important factor related to the amount of antimicrobial in the boar semen extender. Thus, there are short-term (1 to 3 days) (Johnson et al., 1982) and long-term (more than 4 days) extenders (Haugan et al., 2007) and antibacterial concentrations are generally higher in these latter types (Table 1).

In general, the types of antimicrobials addressed in studies on stallion semen conservation are the most varied (Table 1). Arriola and Foote (1982) highlighted that bacterial strains present 
in equine ejaculates were resistant to common antimicrobials such as penicillin and streptomycin. Moreover, it was demonstrated that polymyxin B (Jasko et al., 1993) and gentamicin (Aurich and Spergser, 2007) could negatively affect motility parameters in cooled stallion spermatozoa, despite being potent antimicrobials in semen extenders (Vaillancourt et al., 1993). However, this information was recently contradicted by Price et al. (2008) that reported that the addition of small amounts of gentamicin $(250 \mu \mathrm{g} / \mathrm{mL})$ reduced bacterial growth and improved the sperm motility, velocity and viability in the stallion semen stored at $15{ }^{\circ} \mathrm{C}$ up to $96 \mathrm{~h}$, compared to that of the control, which did not contain any antibacterial substance. Anyway, the cefquinome $(0.99 \mathrm{mg} / \mathrm{mL})$, a fourth-generation cephalosporin, was demonstrated as a suitable substitute for gentamicin within $48 \mathrm{~h}$ preservation of equine semen at $5^{\circ} \mathrm{C}$, providing both the bacterial control and the maintaining of sperm parameters (Parlevliet et al., 2011). Recently, Ramires Neto et al. (2015) reported that the penicillin-gentamicin combination $\left(1,000 \mathrm{IU}-1,000 \mathrm{mg} / \mathrm{mL}\right.$ ) in BotuSemen ${ }^{\circledR}$ (BS) (a skim milk based diluent) yielded lower bacterial load in stallion semen after cooling, compared with INRA $96^{\circledR}$, a commercial diluent, which already contains penicillin $(105 \mu \mathrm{g})$, streptomycin (38 $\left.\mu \mathrm{g}\right)$ and amphotericin B $(0.315 \mu \mathrm{g})$ in its composition. In fact, it was reported that the addition of clavulanic acid-associated ticarcillin (Timentin ${ }^{\circledR}$ ) would be more effective for the bacterial control during equine semen preservation than the isolate use of INRA $96^{\circledR}$ diluent (Olivieri et al.,2011). In addition, the use of the potassium penicillin-amikacin combination has also been evidenced for providing efficient antibacterial action and maintaining sperm parameters during equine semen storage (Varner et al., 1998; Hernández-Avilés et al., 2018; Hernández-Avilés et al., 2019).

For companion animals, protocols for the use of antimicrobials in semen technology are generally extrapolated from other domestic animals and studies focused on the determination of effective antimicrobial concentrations are rare. For instance, Barbosa et al. (2010) found that the isolate use of penicillin at $500 \mathrm{IU}, 1000 \mathrm{IU}$ and $1500 \mathrm{IU} / \mathrm{mL}$ concentrations during canine semen cryopreservation did not control bacterial growth after thawing. Due to the worries on the Mycoplasma sp. and Ureaplasma sp dissemination through canine semen exchange, Becher et al. (2013) addressed the comparison of the effect of two antibiotic combinations, as benzylpenicillin $(0.6 \mathrm{~g} / \mathrm{L})$ plus streptomycin $(1.0 \mathrm{~g} / \mathrm{L})$ and the gentamicin-tylosin-lincomycin-spectinomycin (GTLS) combination at increasing concentrations (GTLS-1: 250, 50, 150 and $300 \mu \mathrm{g} / \mathrm{ml}$; GTLS-2: 500, 100, 300 and $600 \mu \mathrm{g} / \mathrm{ml}$; GTLS-3: 1000, 200, 600 and $1200 \mu \mathrm{g} / \mathrm{ml}$ ), which was demonstrated for being more effective regarding the microbial control.

Studies describing the use of antimicrobials in the preservation of semen from wild animals (Table 1) are even more scarce than in companion animals. The combination of penicillin $(1000 \mathrm{IU} / \mathrm{mL}$ ) and gentamicin $(100 \mu \mathrm{g} / \mathrm{mL}$ ) was effective at preserving koala semen (Phascolarctos cinereus) at $16^{\circ} \mathrm{C}$ for $24 \mathrm{~h}$ as it prevented bacterial growth without interfering on the sperm motility (Johnston et al., 1998). Additionally, the addition of gentamicin $(70 \mu \mathrm{g} / \mathrm{mL}$ ) (Santos et al., 2019a) and a combination of penicillin (2000 IU/mL and $1000 \mathrm{IU} / \mathrm{mL})$-streptomycin $(2 \mathrm{mg} / \mathrm{mL}$ and $1 \mathrm{mg} / \mathrm{mL}$ ) (Santos et al., 2019b) to the semen of collared peccaries (Pecari tajacu) allowed the control of bacterial growth in the samples and did not present toxic effects on the quality of the chilled semen maintained up to $36 \mathrm{~h}$.

Due to the differential action of antimicrobial substances in the distinct species, various studies have been conducted in order to stablish appropriate antimicrobial concentrations in the diluent. The experimental design of the studies does not follow a standardized pattern, and includes several variables, such as type and concentration of antimicrobials, preservation time, storage temperatures, previous inoculation with pathogenic bacteria and fertility trials. In this context, it is evident that the temperature is an important factor that can interfere on bacterial dissemination during semen storage, particularly for stallion and boar cooled-semen technology, in which protocols highlight use of a relatively high temperature $\left(15\right.$ to $\left.17^{\circ} \mathrm{C}\right)$ in a nutrient-rich extender that can favor bacterial growth. However, it was demonstrated that even for stallions (Price et al., 2008) and boars (Waberski et al., 2019), the hypothermic storage $\left(5^{\circ} \mathrm{C}\right.$ ) may reduce the use of antimicrobial drugs (Table 1). 


\section{Alternatives to the use of antibacterial agents}

The development of bacterial resistance against the main antibacterial agents used in semen extenders, such as the combination of penicillin and streptomycin (Sone et al., 1982), amoxicillin, gentamicin, lincomycin, tylosin and spectinomycin (Althouse and Lu, 2005), has been reported. Thus, the search for alternatives that overcome bacterial resistance is a reality. Alternatives include antimicrobial peptides, physical methods for reducing bacterial load and the use of various substances, whether animal, plant or other origins.

\section{Antimicrobial peptides}

Recently, research has been focused on the use of antimicrobial peptides (AMP) that may destabilize the bacterial cell wall (Table 2). Bussalleu et al. (2017) have investigated the use of the proline-arginine-rich antimicrobial peptide, PR-39, which belongs to the group of porcine myeloid antimicrobial peptides 36 (PMAP-36) and 37 (PMAP-37), as an additive to porcine semen extenders. The authors observed that PMAP-37 at 0.5, 1 and $3 \mu \mathrm{M}$ concentrations reduced the bacterial load up to 10 days, besides improving the sperm viability. Moreover, the PR-39 $(20 \mu \mathrm{M})$ promoted bacterial inhibition but it was found to be cytotoxic to the porcine sperm, whereas PMAP-36 did not exhibit any antimicrobial action.

Table 2. Alternative methods for bacterial control in semen samples from mammalian species.

\begin{tabular}{|c|c|c|c|}
\hline Alternatives & Types & Animals & References \\
\hline \multirow{3}{*}{$\begin{array}{l}\text { Antimicrobial } \\
\text { peptides }\end{array}$} & $\begin{array}{l}\text { PR-39 (proline-arginine-rich } \\
\text { antimicrobial peptide) }\end{array}$ & Boar & Bussalleu et al. (2017) \\
\hline & $\begin{array}{l}\text { PBD-1 (beta defensin-1) and } \\
\text { PBD-2 (beta defensin-2) }\end{array}$ & Boar & Puig-Timonet et al. (2018) \\
\hline & $\varepsilon$-Polylysine & Boar & Shaoyong et al. (2019a) \\
\hline \multirow{3}{*}{ Physical methods } & $\begin{array}{l}\text { Single-layer centrifugation } \\
\text { (SLC) }\end{array}$ & Boar & $\begin{array}{l}\text { Morrell and Wallgren (2011), } \\
\text { Morrell et al. (2019) }\end{array}$ \\
\hline & $\begin{array}{l}\text { Single-layer centrifugation } \\
\text { (SLC) }\end{array}$ & Stallion & $\begin{array}{c}\text { Morrell et al. (2014), } \\
\text { Guimarães et al. (2015) }\end{array}$ \\
\hline & Microfiltration & Boar & Barone et al. (2016) \\
\hline \multirow{6}{*}{$\begin{array}{l}\text { Miscellaneous } \\
\text { substances }\end{array}$} & Royal jelly & Bull & Abd-Allah (2010) \\
\hline & Aloe vera gel & $\begin{array}{c}\text { Ram } \\
\text { Collared peccary } \\
\text { (Pecari tajacu) } \\
\text { Bull }\end{array}$ & $\begin{array}{l}\text { Brito et al. (2014) } \\
\text { Souza et al. (2016) } \\
\text { Farias et al. (2019) }\end{array}$ \\
\hline & Kojic acid & Boar & Shaoyong et al. (2019b) \\
\hline & Iodine methionine & Boar & Fang et al. (2017) \\
\hline & BactiBag $^{\circledR}$ & Boar & Camugli et al. (2019) \\
\hline & Sodium alginate & Buffalo & Kumar et al. (2019) \\
\hline
\end{tabular}

Other peptides of porcine origin such as beta defensin-1 (PBD-1) and beta-defensin-2 (PBD-2) may be used as antimicrobial agents. Puig-Timonet et al. (2018) found that both peptides $3 \mathrm{mM}$ concentration did not impair the viability and motility of the spermatozoa and were able to control microbial growth to some extent. Similarly, $\varepsilon$-Polylysine ( 40 to $128 \mathrm{mg} / \mathrm{mL}$ ) was shown for effectively inhibiting bacterial growth, improving sperm quality and in vitro fertilization, being able to replace $50 \%$ of the gentamicin used in the extender (Shaoyong et al., 2019a).

\section{Physical methods}

Some physical methods as centrifugation and filtration (Table 2), which may reduce or replace antimicrobial use, have also been highlighted. An alternative method reported by Morrell and Wallgren (2011) was the use of single-layer centrifugation using Androcoll ${ }^{\mathrm{TM}}-\mathrm{P}, \mathrm{a}$ 
colloid based on glycidoxypropyltrimethoxysilane-coated silic, that completely removed the bacteria from $60 \%$ of the samples of swine semen and reduced the bacterial load in $40 \%$.

Recently, the possibility of separating all sperm from seminal plasma without affecting the semen quality was investigated in swine (Morrell et al., 2019). The ejaculates were diluted in the antimicrobial-free Beltsville Thawing Solution and subjected to single-layer centrifugation in a low-density colloid, which provided an increase on sperm velocity and linearity, besides removing or reducing bacterial contamination in boar ejaculates.

In equine, Morrell et al. (2014) also evaluated the removal of bacteria by single-layer centrifugation using Androcoll ${ }^{\mathrm{TM}}$-E after the addition of bacteria (E. coli, Klebsiella pneumoniae, Streptococcus equi subsp. zooepidemicus, Taylorella equigenitalis, among others) in different proportions in the aliquots of semen. The reduction in counts ranged from $68 \%$ to $97 \%$ among bacteria. In another experiment involving equine semen, it was also found that colloidal centrifugation using Androcoll ${ }^{\mathrm{TM}}$-E before freezing reduced the total bacterial load after thawing and positively influenced the post-thaw motility (Guimarães et al., 2015).

Another physical method recently described for antimicrobial reduction is the seminal plasma (SP) microfiltration. The SP was separated of the sperm by centrifugation, then filtered with a $1.2 \mu \mathrm{m}$ syringe prefilter (NalgeneTM) followed by a $0.22 \mu \mathrm{m}$ syringe filter (NalgeneTM), and added in $20 \%$ of swine fertilization medium with and without antibiotic for Al doses. This process, in addition to reduce bacterial contamination in boar semen, has improved some parameters such as motility, plasma membrane and acrosome integrity, and mitochondrial activity (Barone et al., 2016).

\section{Other alternative substances}

Some recent studies have been considering the use of new natural bioactive products (Table 2) such as phytotherapics and other compounds obtained from plants or animals to replace antibiotics in semen technology.

Abd-Allah (2010) found that the use of $0.4 \%$ royal jelly in the cryopreservation of bovine semen improved the viability and fertility characteristics of the spermatozoa. Although the study did not focus on the use of an antimicrobial activity of the jelly, it has a known antimicrobial component namely 10-hydroxy-2-decenoic acid (Blum et al., 1959), which may also have influenced the results and requires to be investigated.

Another interesting alternative would be the use of Aloe vera, which presents among its constituents a non-volatile fraction with bactericidal action (Radha and Laxmipriya, 2014). Its use was recently reported as an efficient cryoprotectant for ovine (Brito et al., 2014), collared peccary (Souza et al., 2016) and bovine semen (Farias et al., 2019), but its antimicrobial potential during semen preservation was not yet investigated. Besides Aloe vera, the Ocimum gratissimum leaf extract at $0.5 \%$ (Alaba and Sokunbi, 2018) as well as the essential oils of Malaleuca alternifolia and Rosmarinus officinalis, both at $0.4 \mathrm{mg} / \mathrm{mL}$ concentration (Elmi et al., 2019), have shown satisfactory antimicrobial potential in the preservation of wild boar semen.

Other alternative to the antimicrobial drugs includes substances of various origins (Table 2) as the Kojic acid (5-hydroxy-2-hydroxymethyl-1,4-pyrone), which is a weakly acidic secondary metabolite produced by aerobic fermentation of Aspergillus and Acetobacter fungi (Song et al., 2019). It was demonstrated for inhibiting bacterial growth (at concentrations of 20 to $100 \mathrm{mg} / \mathrm{mL}$ ) in diluted swine semen and for improving $(40 \mathrm{mg} / \mathrm{mL})$ sperm quality, sperm capacitation, number of sperm attached to oocyte and embryonic development (Shaoyong et al., 2019b).

Additionally, the iodine methionine, a new type of chelate amino acid, was demonstrated for inhibiting the proliferation of the phylum Proteobacteria and the genus Staphylococcus as well as Pseudomonas, and for improving sperm motility, plasma membrane integrity and acrosome integrity in swine semen after 6 days storage (Fang et al., 2017). Recently, the IMV laboratories reported the use of the BactiBag ${ }^{\circledR}$, a semen bag with bacteriostatic molecules, which shown potential for control bacterial growth during porcine semen storage for 3 days (Camugli et al., 2019). 
Finally, the addition of sodium alginate to egg-yolk diluent improved the metal chelating capacity and antibacterial properties of the extender, besides improving antioxidant and cryoprotective activities during the cryopreservation of buffaloes semen (Kumar et al., 2019).

\section{Final considerations}

The problem of bacterial resistance has been reported since the mid-twentieth century and has stimulated the development of several studies that seek to test new antibacterial agents. However, to date, there are few well-designed studies that have aimed to evaluate the bacteriostatic/bactericidal characteristics of the antimicrobials, their effects on the semen quality of animals, and the time of bioactivity of these compounds under conditions of chilling and freezing.

In general, a variety of antibacterial substances have shown satisfactory results for ruminants and equines, in which antimicrobial drugs are used alone or in combination to increase the spectrum of action. On the other hand, the addition of gentamicin to the porcine semen diluent is well established, but in small and wild animals, studies are scarce and constitute a prominent area for further experimentation.

In parallel, the search for antimicrobial alternatives has been increasing; however, further research is needed to enable the use of adequate concentrations of these new compounds which should be effective for bacterial without impairing the sperm quality. Furthermore, in the long term, the in vivo effect of these substances on fertility after the use of chilled or cryopreserved semen by Al should be evaluated.

\section{References}

Abd-Allah SM. Effect of royal jelly on bovine sperm characteristics during post-thaw incubation in vitro. Rev Vet. 2010;21(2):81-5.

Akhter S, Ansari MS, Andrabi S, Ullah N, Qayyum M. Effect of antibiotics in extender on bacterial and spermatozoal quality of cooled buffalo (Bubalus bubalis) bull semen. Reprod Domest Anim. 2008;43(3):272-8. http://dx.doi.org/10.1111/j.1439-0531.2007.00890.x. PMid:18042206.

Akhter S, Ansari MS, Rakha BA, Andrabi SMH, Qadeer S, Iqbal R, Ullah N. Efficiency of ciprofloxacin for bacterial control, post-thaw quality, and in vivo fertility of buffalo spermatozoa. Theriogenology. 2013;80(4):378-83. http://dx.doi.org/10.1016/j.theriogenology.2013.05.001. PMid:23746693.

Alaba O, Sokunbi OA. Antibacterial effects of scent leaf extract (Ocimum gratissimum L.) on quality of extended porcine semen. Anim Reprod Sci. 2018;194:e16. http://dx.doi.org/10.1016/j.anireprosci.2018.04.038.

Alford JA. The occurrence of bacteria resistant to penicillin, streptomycin, and sulfanilamide in diluted bull semen. J Dairy Sci. 1953;36(10):1097-103. http://dx.doi.org/10.3168/jds.S0022-0302(53)91603-8.

Almond G, Poolperm P. Semen contamination and choosing antibiotics. In: Abstracts of the 5th North Carolina Healthy Hogs Seminar; 1996 Oct; Greenville, United States. Greenville: North Carolina Swine Veterinary Group; 1996.

Almquist JO. A comparison of Penicillin, Streptomycin and Sulfanilamide for improving the fertility of semen from bulls of low fertility. J Dairy Sci. 1951;34(8):819-22. http://dx.doi.org/10.3168/jds.S00220302(51)91787-0.

Almquist JO, Glantz PJ, Shaffers HE. The effect of a combination of Penicillin and Streptomycin upon the livability and bacterial content of bovine semen. J Dairy Sci. 1949;32(2):183-90. http://dx.doi.org/10.3168/jds.S0022-0302(49)92025-1.

Althouse GC, Kuster C, Clark S, Weisiger R. Field investigations of bacterial contaminants and their effects on extended porcine semen. Theriogenology. 2000;53(5):1167-76. http://dx.doi.org/10.1016/S0093691X(00)00261-2. PMid:10798493.

Althouse GC, Lu KG. Bacteriospermia in extended porcine semen. Theriogenology. 2005;63(2):573-84. http://dx.doi.org/10.1016/j.theriogenology.2004.09.031. PMid:15626417.

Andrabi SMH, Ahmad N, Abbas A, Anzar M. Effect of two different antibiotic combinations on fertility of frozen buffalo and Sahiwal bull semen. Pak Vet J. 2001;21(4):166-9. 
Andrabi SMH, Khan LA, Shahab M. Isolation of bacteria in semen and evaluation of antibiotics in extender for cryopreservation of buffalo (Bubalus bubalis) bull spermatozoa. Andrologia. 2016;48(10):1166-74. http://dx.doi.org/10.1111/and.12555. PMid:26892806.

Arriola $\mathrm{RH}$, Foote AJ. Effects of amikacin sulfate on the motility of stallion and bull spermatozoa at different temperatures and intervals of storage. J Anim Sci. 1982;54(6):1105-10. http://dx.doi.org/10.2527/jas1982.5461105x. PMid:7107529.

Aurich C, Spergser J. Influence of bacteria and gentamicin on cooled-stored stallion spermatozoa. Theriogenology. 2007;67(5):912-8. http://dx.doi.org/10.1016/j.theriogenology.2006.11.004. PMid:17141306.

Azawi OI, Ismaeel MA. Influence of addition of different antibiotics in semen diluent on viable bacterial count and spermatozoal viability of Awassi ram semen. Vet World. 2012;5(2):75-9. http://dx.doi.org/10.5455/vetworld.2012.75-79.

Barbosa CC, Madeira VLH, Jucá RP, Oliveira AC, Uchoa DC, Pinheiro AQ, Silva LDM. Different concentration of benzylpenicillin benzatin addition on cryopreserved canine semen using a powdered coconut water extender (ACP-106 ${ }^{\circledR}$ ). Rev Bras Saúde Prod Anim. 2010;11(1):270-81.

Barone F, Ventrella D, Zannoni A, Forni M, Bacci ML. Can microfiltered seminal plasma preserve the morphofunctional characteristics of porcine spermatozoa in the absence of antibiotics? A preliminary study. Reprod Domest Anim. 2016;51(4):604-10. http://dx.doi.org/10.1111/rda.12699. PMid:27174664.

Becher AC, Spergser J, Aurich C, Zottler E, Aurich JE, Schäfer-Somi S. Cooled storage of canine semen: in vitro effects of different concentrations of an antibiotic combination on growth of mollicutes. Reprod Domest Anim. 2013;48(6):961-6. http://dx.doi.org/10.1111/rda.12194. PMid:23808480.

Blum MS, Novak AF, Taber S 3rd. 10-Hydroxy-delta2-decenoic acid, an antibiotic found in royal jell. Science. 1959;130(3373):452-3. http://dx.doi.org/10.1126/science.130.3373.452. PMid:13675771.

Brasil. Ministério da Agricultura, Pecuária e Abastecimento. Instrução Normativa $n^{\circ} 48$, de 17 de junho de 2003. Regulamenta os requisitos sanitários mínimos para a produção e comercialização de sêmen bovino e bubalino no país. Diário Oficial da União. 2003; seção 1: 6-7. Portuguese.

Brasil. Ministério da Agricultura, Pecuária e Abastecimento. Instrução Normativa $n^{\circ} 1$, de 22 de janeiro de 2014. Estabelece os requisitos sanitários para processamento e comercialização de sêmen de caprinos e de ovinos no território brasileiro. Diário Oficial da União. 2014; seção 1. Portuguese.

Brito BF, Antunes LP, Rodrigues FRN, Salgueiro CCM, Cavalcante JMM, Nunes JF. Effect of Aloe vera added in different concentrations to Powdered Coconut Water (ACP-102 ${ }^{\circledR}$ ) in ram semen diluted and incubated for two hours. Acta Vet Brasilica. 2014;8:242-3. http://dx.doi.org/10.21708/avb.2014.8.0.

Bryła M, Trzcinska M. Quality and fertilizing capacity of boar spermatozoa during liquid storage in extender supplemented with different antibiotics. Anim Reprod Sci. 2015;163:157-63. http://dx.doi.org/10.1016/j.anireprosci.2015.11.005. PMid:26586542.

Bussalleu E, Torner E. Quality improvement of boar seminal doses. In: Bonet S, Casas I, Holt WV, Yeste M, editors. Boar reproduction. Fundamentals and new biotechnological trends. Heidelberg: SpringerVerlag; 2013. p. 517-50.

Bussalleu E, Sancho S, Briz MD, Yeste M, Bonet S. Do antimicrobial peptides PR-39, PMAP-36 and PMAP37 have any effect on bacterial growth and quality of liquid-stored boar semen? Theriogenology. 2017;89:235-43. http://dx.doi.org/10.1016/j.theriogenology.2016.11.017. PMid:28043357.

Camugli S, Eterpi M, Gavin-Plagne L, Gonzalez A, Gorges J-C, Vanssay A, Schmitt É. Bactibag ${ }^{\circledR}$ : An opportunity to reduce the use of antibiotics in boar semen processing. Theriogenology. 2019;137:128. http://dx.doi.org/10.1016/j.theriogenology.2019.05.052.

Costa PM, Martins CF. Conservation of animal genetic resources through reproductive biotechniques. Univ Ci Saúde. 2008;6:39-55.

Diemer T, Huwe P, Michelmann HW, Mayer F, Schiefer HG, Weidner W. Escherichia coli-induced alterations of human spermatozoa. An electron microscopy analysis. Int J Androl. 2000;23(3):178-86. http://dx.doi.org/10.1046/j.1365-2605.2000.00224.x. PMid:10844544.

Elmi A, Prosperi A, Zannoni A, Bertocchi M, Scorpio DG, Forni M, Foni E, Bacci ML, Ventrella D. Antimicrobial capabilities of non-spermicidal concentrations of tea tree (Melaleuca alternifolia) and rosemary (Rosmarinus officinalis) essential oils on the liquid phase of refrigerated swine seminal doses. Res Vet Sci. 2019;127:76-81. http://dx.doi.org/10.1016/j.rvsc.2019.10.014. PMid:31678456. 
European Union. Council Directive 88/407/EEC of 14 June 1988 laying down the animal health requirements applicable to intra-community trade in and imports of deep-frozen semen of domestic animals of the bovine species. Official Journal of the European Communities; Bruxels; 22 July 1988. L194:10-23.

European Union. Council Directive 90/429/EEC of 26 June 1990 laying down the animal health requirements applicable to intra-community trade in and imports of semen of domestic animals of the porcine species. Official Journal of the European Communities; Bruxels; 18 August 1990. L224:6273.

European Union. Council Directive 92/65/EEC of 13 July 1992 laying down animal health requirements governing trade in and imports into the Community of animals, semen, ova and embryos not subject to animal health requirements laid down in specific Community rules referred to in Annex A (I) to Directive 90/425/EEC. Official Journal of the European Communities; Bruxels; 13 July 1992. L268:5472.

Fang Q, Wang J, Hao YY, Li H, Hu JX, Yang GS, Hu JH. Effects of iodine methionine on boar sperm quality during liquid storage at $17^{\circ} \mathrm{C}$. Reprod Domest Anim. 2017;52(6):1061-6. http://dx.doi.org/10.1111/rda.13024. PMid:28691287.

Farias CFA, Tork ALP, Rique AS, Queirós AF, Silva SV. Study of Aloe vera efficacy as a plant origin extender in the cooling on bovine epididymal spermatozoa. Rev Bras Reprod Anim. 2019;43(3):787-94.

Foote RH. The history of artificial insemination: selected notes and notables. J Anim Sci. 2002;80(2):1-10. http://dx.doi.org/10.2527/animalsci2002.80E-Suppl_21a.

Gączarzewicz D, Udała J, Piasecka M, Błaszczyk B, Stankiewicz T. Bacterial contamination of boar semen and its relationship to sperm quality preserved in commercial extender containing gentamicin sulfate. Pol J Vet Sci. 2016;19(3):451-9. http://dx.doi.org/10.1515/pjvs-2016-0057. PMid:27760038.

Gloria A, Contri A, Wegher L, Vignola G, Dellamaria D, Carluccio A. The effects of antibiotic additions to extenders on fresh and frozen-thawed bull semen. Anim Reprod Sci. 2014;150(1-2):15-23. http://dx.doi.org/10.1016/j.anireprosci.2014.08.012. PMid:25239841.

Guimarães T, Lopes G, Pinto M, Silva E, Miranda C, Correia MJ, Damásio L, Thompson G, Rocha A. Colloid centrifugation of fresh stallion semen before cryopreservation decreased microorganism load of frozen-thawed semen without affecting seminal kinetics. Theriogenology. 2015;83(2):186-91. http://dx.doi.org/10.1016/j.theriogenology.2014.09.003. PMid:25287189.

Haugan T, Gaustad AH, Reksen O, Gröhn YT, Hofmo PO. Fertility results of artificial inseminations performed with liquid boar semen stored in X-cell vs BTS extender. Reprod Domest Anim. 2007;42(1):94-9. http://dx.doi.org/10.1111/j.1439-0531.2006.00738.x. PMid:17214781.

Hernández-Avilés C, Love CC, Serafini R, Teague SR, Varner DD. Supplemental antibiotics in a commercial extender for stallion semen. J Equine Vet Sci. 2019;80:33-5. http://dx.doi.org/10.1016/j.jevs.2019.06.014. PMid:31443830.

Hernández-Avilés C, Serafini R, Love CC, Teague SR, LaCaze KA, Lawhon SD, Wu J, Blanchard TL, Varner $\mathrm{DD}$. The effects of antibiotic type and extender storage method on sperm quality and antibacterial effectiveness in fresh and cooled-stored stallion semen. Theriogenology. 2018;122:23-9. http://dx.doi.org/10.1016/j.theriogenology.2018.08.022. PMid:30219312.

Jasko DJ, Bedford SJ, Cook NL, Mumford EL, Squires EL, Pickett BW. Effect of antibiotics on motion characteristics of cooled stallion spermatozoa. Theriogenology. 1993;40(5):885-93. http://dx.doi.org/10.1016/0093-691X(93)90356-A.

Johnson LA, Aalbers JG, Willems CM, Rademaker JH, Rexroad CE Jr. Use of boar spermatozoa for artificial insemination. III. Fecundity of boar spermatozoa stored in Beltsville liquid and Kiev extenders for three days at $18{ }^{\circ} \mathrm{C}$. J Anim Sci. 1982;54(1):132-6. http://dx.doi.org/10.2527/jas1982.541132x. PMid:7200975.

Johnston SD, O'Boyle D, Frost AJ, McGowan MR, Tribe A, Higgins D. Antibiotics for the preservation of koala (Phascolarctos cinereus) semen. Aust Vet J. 1998;76(5):335-8. http://dx.doi.org/10.1111/j.17510813.1998.tb12362.x. PMid:9631702.

Kumar P, Pawaria S, Dalal J, Ravesh S, Bharadwaj S, Jerome A, Kumar D, Jan MH, Yadav PS. Sodium alginate potentiates antioxidants, cryoprotection and antibacterial activities of egg yolk extender during semen cryopreservation in buffalo. Anim Reprod Sci. 2019;209:106166. http://dx.doi.org/10.1016/j.anireprosci.2019.106166. PMid:31514937.

Maes D, Nauwynck H, Rijsselaere T, Mateusen B, Vyt P, De Kruif A, Van Soom A. Diseases in swine transmitted by artificial insemination: An overview. Theriogenology. 2008;70(8):1337-45. http://dx.doi.org/10.1016/j.theriogenology.2008.06.018. PMid:18657310. 
Mazurova J, Krpatova J. The risks of the cryopreservation of bull semen. Veterinarstvi. 1990;40(9):402-4.

Mazurová J, Vinter P. The effect of selected antibiotics on microorganisms contaminating boar ejaculate. Vet Med (Praha). 1991;36(4):213-23. PMid:1771724.

Morrell JM, Klein C, Lundeheim N, Erol E, Troedsson MHT. Removal of bacteria from stallion semen by colloid centrifugation. Anim Reprod Sci. 2014;145(1-2):47-53. http://dx.doi.org/10.1016/j.anireprosci.2014.01.005. PMid:24485764.

Morrell JM, Mayer I. Reproduction biotechnologies in germplasm banking of livestock species: a review. Zygote. 2017;25(5):545-57. http://dx.doi.org/10.1017/S0967199417000442. PMid:28835292.

Morrell JM, Núñez-González A, Crespo-Félez I, Martínez-Martínez S, Martínez Alborcia M-J, FernándezAlegre E, Dominguez JC, Gutiérrez-Martín CB, Martínez-Pastor F. Removal of bacteria from boar semen using a low-density colloid. Theriogenology. 2019;126:272-8. http://dx.doi.org/10.1016/j.theriogenology.2018.12.028. PMid:30594102.

Morrell JM, Wallgren M. Removal of bacterial from boar ejaculates by single layer centrifugation can reduce the use of antibiotics in semen extenders. Anim Reprod Sci. 2011;123(1-2):64-9. http://dx.doi.org/10.1016/j.anireprosci.2010.11.005. PMid:21145185.

Moustacas VS, Xavier MN, Carvalho-Júnior CA, Costa EA, Henry M, Santos RL. Effect of extender supplementation with various antimicrobial agents on viability of Brucella ovis and Actinobacillus seminis in cryopreserved ovine semen. Theriogenology. 2010;74(8):1476-81. http://dx.doi.org/10.1016/j.theriogenology.2010.06.019. PMid:20708246.

Olivieri BT, Love BC, Rezabek GB, Lamm CG, Varner DD, Payton ME, Holyoak GR. Effect of Antibioticcontaining Extenders on Taylorella equigenitalis Contaminated Semen. J Equine Vet Sci. 2011;31(11):655-60. http://dx.doi.org/10.1016/j.jevs.2011.04.002.

Parlevliet JM, Lynn JW, Paccamonti DL. The use of Cefquinome in equine semen extender. J Equine Vet Sci. 2011;31(3):139-42. http://dx.doi.org/10.1016/j.jevs.2010.12.015.

Price S, Aurich J, Davies-Morel M, Aurich C. Effects of oxygen exposure and gentamicin on stallion semen stored at 5 and $15^{\circ} \mathrm{C}$. Reprod Domest Anim. 2008;43(3):261-6. http://dx.doi.org/10.1111/j.14390531.2007.00888.x. PMid:18042208.

Prieto-Martínez N, Bussalleu E, Garcia-Bonavila E, Bonet S, Yeste M. Effects of Enterobacter cloacae on boar sperm quality duringliquid storage at $17^{\circ} \mathrm{C}$. Anim Reprod Sci. 2014;148(1-2):72-82. http://dx.doi.org/10.1016/j.anireprosci.2014.05.008. PMid:24880981.

Puig-Timonet A, Castillo-Martín M, Pereira BA, Pinart E, Bonet S, Yeste M. Evaluation of porcine beta defensins- 1 and -2 as antimicrobial peptides for liquid-stored boar semen: effects on bacterial growth and sperm quality. Theriogenology. 2018;111:9-18. http://dx.doi.org/10.1016/j.theriogenology.2018.01.014. PMid:29407425.

Radha MH, Laxmipriya NP. Evaluation of biological properties and clinical effectiveness of Aloe vera: A systematic review. J Tradit Complement Med. 2014;5(1):21-6. http://dx.doi.org/10.1016/j.jtcme.2014.10.006. PMid:26151005.

Ramires Neto C, Sancler da Silva YFR, Resende HL, Guasti PN, Monteiro GA, Papa PM, Dell'Aqua Júnior JA, Puoli Filho JNP, Alvarenga MA, Papa FO. Control methods and evaluation of bacterial growth on fresh and cooled stallion semen. J Equine Vet Sci. 2015;35(4):277-82. http://dx.doi.org/10.1016/j.jevs.2015.01.014.

Santos CS, Dantas MRT, Rebouças MCG, Silva AM, Praxedes ECG, Campos LB, Oliveira MF, Silva AR. Adição de gentamicina ao diluente reduz a carga bacteriana e não afeta a qualidade do sêmen refrigerado de catetos (Pecari tajacu). In: Abstracts of the 23th Congresso Brasileiro de Reprodução Animal; 2019 May 15-17; Gramado, Brazil. Gramado: CBRA; 2019a. p. 701.

Santos CS, Dantas MRT, Rebouças MCG, Silva AM, Praxedes ECG, Campos LB, Oliveira MF, Silva AR. Efeito da inclusão de penicilina-estreptomicina no diluente para refrigeração do sêmen de catetos (Pecari tajacu). In: Abstracts of the 23th Brazilian Congress of Animal Reproduction; 2019 May 15-17; Gramado, Brazil. Gramado: CBRA; 2019b. p. 708.

Schulze M, Grobbel M, Riesenbeck A, Brüning S, Schaefer J, Jung M, Grossfeld R. Dose rates of antimicrobial substances in boar semen preservation-time to establish new protocols. Reprod Domest Anim. 2017;52(3):397-402. http://dx.doi.org/10.1111/rda.12921. PMid:28066955.

Sepúlveda L, Bussalleu E, Yeste M, Bonet S. Effects of different concentrations of Pseudomonas aeruginosa on boar sperm quality. Anim Reprod Sci. 2014;150(3-4):96-106. http://dx.doi.org/10.1016/j.anireprosci.2014.09.001. PMid:25255782. 
Shaoyong W, Li Q, Ren Z, Wei C, Chu G, Dong W, Yang GS, Pang WJ. Evaluation of $\varepsilon$-polylysine as antimicrobial alternative for liquid-stored boar semen. Theriogenology. 2019a;130:146-56. http://dx.doi.org/10.1016/j.theriogenology.2019.03.005. PMid:30897429.

Shaoyong W, Li Q, Ren Z, Xiao J, Diao Z, Yang G, Pang W. Effects of kojic acid on boar sperm quality and anti-bacterial activity during liquid preservation at 17 C. Theriogenology. 2019b;140:124-35. http://dx.doi.org/10.1016/j.theriogenology.2019.08.020. PMid:31473495.

Sone M, Ohmura K, Bamba K. Effects of various antibiotics on the control of bacteria in boar semen. Vet Rec. 1982;111(1):11-4. http://dx.doi.org/10.1136/vr.111.1.11. PMid:6287697.

Song L, Xie W, Zhao Y, Lv X, Yang H, Zeng Q, et al. Synthesis, antimicrobial, moisture absorption and retention activities of kojic acid-grafted konjac glucomannan oligosaccharides. Polymers. 2019;11(12):1-12. https://doi.org/10.3390/polym11121979.

Souza ALP, Lima GL, Peixoto GCX, Silva AM, Oliveira MF, Silva AR. Use of Aloe vera-based extender for chilling and freezing collared peccary (Pecari tajacu) semen. Theriogenology. 2016;85(8):1432-8. http://dx.doi.org/10.1016/j.theriogenology.2016.01.007. PMid:26830302.

Spinosa HS, Gorniak SL, Bernardi MM. Farmacologia aplicada à medicina veterinária. 5nd ed. Rio de Janeiro: Guanabara Koogan; 2011.

Thibier M, Guerin B. Hygienic aspects of storage and use of semen for artificial insemination. Anim Reprod Sci. 2000;62(1-3):233-51. http://dx.doi.org/10.1016/S0378-4320(00)00161-5. PMid:10924827.

Vaillancourt D, Guay P, Higgins R. The effectiveness of gentamicin or polymyxin B for the control of bacterial growth in equine semen stored at 20 degrees $C$ or 5 degrees $C$ for up to forty-eight hours. Can J Vet Res. 1993;57(4):277-80. PMid:8269366.

Varner DD, Scanlan CM, Thompson JA, Brumbaugh GW, Blanchard TL, Carlton CM, Johnson L. Bacteriology of preserved stallion semen and antibiotics in semen extenders. Theriogenology. 1998;50(4):559-73. http://dx.doi.org/10.1016/S0093-691X(98)00161-7. PMid:10732147.

Waberski D, Luther A-M, Grünther B, Jäkel H, Henning H, Vogel C, Peralta W, Weitze KF. Sperm function in vitro and fertility after antibiotic-free, hypothermic storage of liquid preserved boar semen. Sci Rep. 2019;9(1):1-10. http://dx.doi.org/10.1038/s41598-019-51319-1. PMid:31611589.

Woelders H, Windig J, Hiemstra SJ. How developments in cryobiology, reproduction technologies and conservation genomics could shape gene banking strategies for (farm) animals. Reprod Domest Anim. 2012;47(Suppl. 4):264-73. http://dx.doi.org/10.1111/j.1439-0531.2012.02085.x. PMid:22827380

Zampieri D, Santos VG, Braga PA, Ferreira CR, Ballottin D, Tasic L, Basso AC, Sanches BV, Pontes JH, Silva BP, Garboggini FF, Eberlin MN, Tata A. Microorganisms in cryopreserved semen and culture media used in the In Vitro Production (IVP) of bovine embryos identified by Matrix-Assisted Laser Desorption Ionization Mass Spectrometry (MALDI-MS). Theriogenology. 2013;80(4):337-45. http://dx.doi.org/10.1016/j.theriogenology.2013.04.020. PMid:23756041.

\section{Author contributions}

CSS: Conceptualization, Data curation, Formal analysis, Methodology, Writing - original draft, Writing - review \& editing; ARS: Conceptualization, Methodology, Supervision, Writing - original draft, Writing - review \& editing. 